\title{
Prevalence of Hepatitis B Virus, Genotypes, and Mutants in HBsAg-Positive Patients in Meerut, India
}

\author{
Salman Khan ${ }^{1 *}$, Molly Madan ${ }^{1}$ and Sunil Kumar Virmani ${ }^{2}$ \\ ${ }^{1}$ Department of Microbiology, Netaji Subhash Chandra Bose Subharti Medical College, Swami Vivekanand \\ Subharti University, Meerut, Uttar Pradesh, India; ${ }^{2}$ Department of Medicine, Netaji Subhash Chandra Bose \\ Subharti Medical College, Swami Vivekanand Subharti University, Meerut, Uttar Pradesh, India
}

Received 16 April 2018; revised 6 October 2018; accepted 8 October 2018

\begin{abstract}
Background: Genetic changeability of hepatitis B virus (HBV) signifies a challenge for the sensitivity of immunologic and molecular diagnostics. Therefore, knowing the spread of HBV genotypes (GENs) and mutation has considerable impacts on treatment strategies, vaccination program, diagnosis, and prevention. The present study aimed to detect HBV GENs and mutants in HBsAg-positive patients. Methods: The study conducted on 4927 patients in Meerut, India, between March 2013 and April 2017. The blood specimens were analyzed for HBsAg using an ELISA kit, then the blood samples from HBsAg-positive patients were subjected to HBeAg assay and DNA isolation. Amplification of the HBV DNA of pre-S gene and pre-core or basal core promoter region were performed by RT-PCR and sequenced to analyze both GEN and mutation. Results: According to the results, 245 cases were positive for HBsAg, and 55 were HBeAg-positive. With regard to HBV DNA levels, 16 samples were found positive in PCR assay with 7 (43.8\%) less than $2000 \mathrm{IU} / \mathrm{mL}, 4(25 \%)$ between $>2000$ and $20,000 \mathrm{IU} / \mathrm{mL}$, and $5(3.25 \%)$ $>20,000 \mathrm{IU} / \mathrm{mL}$. No mutations were detected in GENs B and A. The prevalence of HBV GENs B and A were $68.8 \%$ ( $\mathrm{n}$ $=11)$ and $31.25 \%(n=6)$, respectively. Conclusion: GEN-B was more prevalent in comparison to GEN-A. The genetic diversity of HBV and distribution of its GENs and mutation improve the current knowledge of epidemiological, clinical and virological patterns of hepatitis B in this region, which help physicians to prescribe proper antiviral/interferon therapy according to current genotyping pattern. DOI: 10.29252/ibj.23.5.354
\end{abstract}

Keywords: Genotype, Hepatitis B surface antigens, Hepatitis B virus, India, Mutation

Corresponding Author: Salman Khan

Department of Microbiology, Neta ji Subhash Chandra Bose Subharti Medical College, Swami Vivekanand Subharti University, Meerut,

Uttar Pradesh, India; Mobile: (+91)8 791288978; E-mail: salman186631@gmail.com

\section{INTRODUCTION}

$\mathrm{H}$ uman hepatitis B virus (HBV) is a small DNA virus inflicting acute and chronic hepatitis. Notwithstanding the availability of a secure and powerful vaccine, HBV infection (HBVI) is, nevertheless, a massive international health hazard. It chronically afflicts about 240 to 300 million humans worldwide, and about 600,000 deaths occur every year due to HBV-related liver pathologies ${ }^{[1]}$.

HBV is mainly found in secretions of vagina, semen, blood, saliva, and menstrual blood of infected patients and can be transmitted to the uninfected individuals via contact with the body fluids of infected patients ${ }^{[2]}$. Meanwhile, in households of chronically infected individuals, HBVI can be transmitted from person-toperson, even through nonsexual contact ${ }^{[3]}$. The virus is most commonly transmitted vertically in the world ${ }^{[4]}$. In India, almost 3-4\% of the population is infected with HBV, and more than $50 \%$ of the cases become chronic. This incidence, seen within the context of India's huge populace and in the absence of a national immunization program, could trigger an increasing outbreak of infection and liver disease due, in large part, to HBV. Thus, given the government's apathetic attitude, the HBV epidemiology in India is ended up severely due 
to the probability that India may emerge as the country with the largest HBVI pool internationally in near future $^{[5]}$.

Phylogenetic evaluation has divided the type of HBV into eight genotypes (GENs), defined by using an intergroup divergence of $>8 \%$ inside the whole genome series $^{[6,7]}$ and of $>4 \%$ inside the $\mathrm{S}$ gene ${ }^{[8]}$. Since the first description of four GENs (A-D) of $\mathrm{HBV}$ in $1988^{[7]}$, four more have been identified, distinctive E, F, G, and H. Furthermore, sub-GENs with distinctive series traits and a divergence inside the whole genome of $>4 \%$ have been shown to locate inside GENs A, B, $\mathrm{C}$, and $\mathrm{F}^{[9,10]}$. The prognosis, initial clinical symptoms, and response to treatment may differ from GEN to GEN in infected patients and there is a variation in geographic distribution of different GENs ${ }^{[11]}$. The pathogenic variations among HBV GENs have been in part clarified. Intracellular expression ranges of $\mathrm{HBV}$ DNA and HBV core antigen ( $\mathrm{HBcAg}$ ), in addition to the extracellular titers of HBV DNA and $\mathrm{HBeAg}$ have been observed to be higher for HBV GENs B and $\mathrm{C}$ than for $A$ and D. The intracellular accumulation of HBV DNA and viral antigens may additionally play a crucial part in the induction of liver cellular damage. Moreover, the greater replication capability of GEN C may also explain why it is by far the GEN associated with the most extreme HBV-induced liver disease ${ }^{[12,13]}$.

Pre-core mutants are HBV variations that appear for the duration of $\mathrm{HBeAg}$ sero-conversion. The most common location of such mutations is a guanine to adenine substitution at nucleotide 1896, creating a premature stop-codon at the pre-core region ${ }^{[14]}$. The core promoter region is situated upstream to the precore region; the regulation of viral replication occurs at this region and consists of an upstream regulatory sequence and a basal core promoter. A1762T and G1764A nucleotide exchange is a mutation that occurs in the core promoter region, resulting in enhanced viral genome replication and substantial reduction in HBeAg expression ${ }^{[15]}$. The intention of the existing research was to assess the sero-occurrence of $\mathrm{HBV}$ as well as detection of $\mathrm{HBV}$ GENs and mutants in Meerut, India

\section{MATERIALS AND METHODS}

\section{Study background and subjects}

This study was conducted on 4927 patients. Blood samples obtained from suspected HBVIs, and the sequelae patients from Meerut were collected in a clean, sterile and small test tube and processed in the Central Research Station Laboratory of Microbiology at Netaji Subhash Chandra Bose Subharti Medical
College (Meerut, India) between March 2013 and April 2017.

\section{Sample collection and processing}

Ten $\mathrm{ml}$ of blood samples was received from patients and analyzed in the laboratory. The sera were separated and screened for HBsAg by Hepa Card (J. Mitra \& Co. Pvt. Ltd., New Delhi, India), and positive sera were stored frozen $\left(-20{ }^{\circ} \mathrm{C}\right)$ until tested for viral markers. The HBsAg-positive serum samples were tested for HBsAg using a commercially available ELISA kit (ERBA Transasia Bio-medicals Ltd. Daman, India). The positive serum samples were retested for $\mathrm{HBeAg}$ (ELISA; Beijing Kewei Clinical Diagnostic Reagent Inc., Beijing, China). DNA isolation from the serum samples was performed using the QIAamp DNA Mini Kit (Qiagen, Germany) and based on the manufacturer's recommendations. The isolated DNA was amplified by RGQ real-time PCR using the artus HBV RG PCR Kit (Qiagen, Germany) according to the recommendations provided by the manufacturer. Two sets of primers (two forward and two reverse) were used for both Pre-S gene and Pre-core/core region and one set for detecting the existence of $\mathrm{HBV} / \mathrm{B}$ in a mixed population. A GEN B-specific PCR using HBV/B GEN-specific primers (PS-B1 and PS-B2) was also performed (Table 1).

\section{Real-time PCR profile (cycling conditions)}

PCR was carried out in a thermal cycler as follow: an initial denaturation at $95{ }^{\circ} \mathrm{C}$ for $10 \mathrm{~min}$ and 45 cycles of $95{ }^{\circ} \mathrm{C}$ for $15 \mathrm{~s}, 55{ }^{\circ} \mathrm{C}$ for $30 \mathrm{~s}$, and elongation at $72{ }^{\circ} \mathrm{C}$ for $15 \mathrm{~s}$.

\section{Data interpretation and analysis}

Data analysis was performed with Rotor Gene Q software (Qiagen, USA) as per the manufacturer's instructions. After the completion of PCR, the data was acquired on FAM/Sybr (Green) and JOE (Yellow) channels. If the HBV DNA was positive, the signal was detected in fluorescence channel of Cycling Green, and if negative, the signal was detected in fluorescence channel of Cycling Yellow (the internal control). TRUGENE HBV kit was used to genotype and to find out mutation in amplified HBV DNA (https://www. labmedica.com/whitepapers/Trugene_HBV_Assay_Fin al_cover_8.28.pdf) whose sequencing of Amplified HBV DNA was performed by cross-linking immunoprecipitation method using the same PCR primers. The software assigned the viral GEN and the mutations and polymorphisms present in the sample. The TRUGENE HBV module contains sequences that correspond to the $\mathrm{S}$ gene, $\mathrm{C}$ gene, polymerase regions for GEN A through $\mathrm{H}$, and a universal mutation 
Table 1. Real-Time PCR primers for genotyping and mutants

\begin{tabular}{cclcc}
\hline S.N. & Primer & Nucleotide sequence (5' to 3') & Position (nt) & Polarity \\
\hline Pre-S gene & & & & \\
1 & PS1 & GGGTCACCTTATTCTTGGGA & $2814-2833$ & $\mathrm{~F}$ \\
2 & PS2 & CCCCGCCTGTAACACGAGCA & $208-189$ & $\mathrm{R}$ \\
3 & PS3 & TTGGGAACAAGATCTACAGC & $2828-2847$ & $\mathrm{~F}$ \\
4 & PS4 & GTCCTGATGCGATGTTCTCC & $176-157$ & $\mathrm{R}$ \\
5 & PS-B1 & ATTCAAAGCCAACTCAGAAA & $2946-2965$ & $\mathrm{~F}$ \\
6 & PS-B2 & ACAGTATTCTGAGCAGGGCTC & $105-85$ & $\mathrm{R}$ \\
\multicolumn{2}{r}{ Pre-core/core region } & & & \\
1 & PC1 & ACATAAGAGGACTCTTGGAC & $1652-1671$ & $\mathrm{~F}$ \\
2 & PC2 & GAAGGAAAGAAGTCAGAAGGC & $1977-1957$ & $\mathrm{R}$ \\
3 & PC3 & TACTTCAAAGACTGTGTGTTTA & $1704-1725$ & $\mathrm{~F}$ \\
4 & PC4 & GTCAGAAGGCAAAAAAGAGA & $1966-1947$ & $\mathrm{R}$ \\
\hline
\end{tabular}

$\mathrm{F}$, forward; R, reverse

reporting reference sequence for comparison. The sequence file was generated by Gene Object ${ }^{\mathrm{TM}}$ software (Fig. 1) and was analyzed on NCBI website for HBV genotyping and also analyzed in Bioedit software (http://www.mbio.ncsu.edu/BioEdit/bioedit. html) to find out mutation.

\section{Statistical analysis}

Obtained data were analyzed by using the SPSS software for windows version 16. Comparison of data in respect to age groups and gender was performed by Z-test. $p<0.05$ was considered to be statistically significant.

\section{RESULTS}

In total, 4927 patients, $2218(45.01 \%)$ males and $2709(54.98 \%)$ females, were included in this study, and those in the range of 21-65 years of age were analyzed for $\mathrm{HBsAg}$. The seroprevalence of overall cases was $4.97 \%$ (Fig. 2). Besides, 245 cases were detected as positive and 4682 as negative. Of 4682 negative cases, 2100 were males and 2582 were females.
However, of 245 positive cases, 118 (48.16\%) were males and 127 (51.84\%) were females, and this was statistically non-significant $(p>0.601)$ by using Z-test (Fig. 3). The sero-occurrence of total males and females were $5.32 \%$ and $4.69 \%$, respectively (Table 2 ).

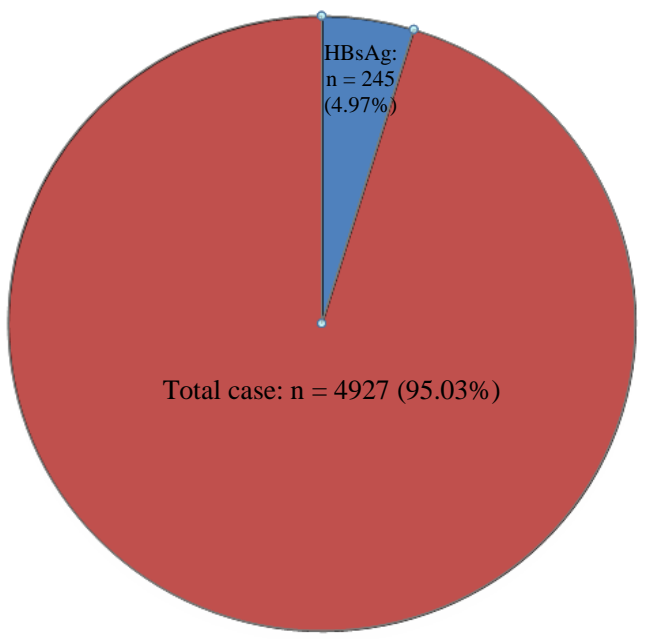

Fig. 2. Prevalence of hepatitis B virus.

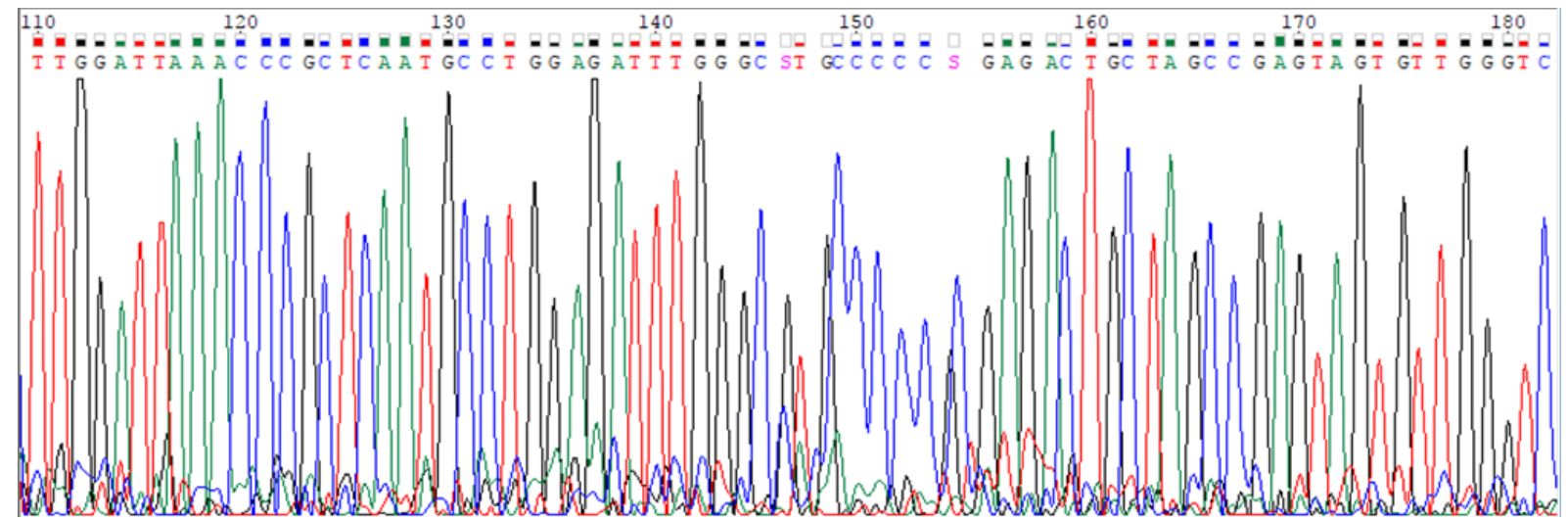

Fig. 1. HBV gene sequencing in open gene DNA sequencing system. 


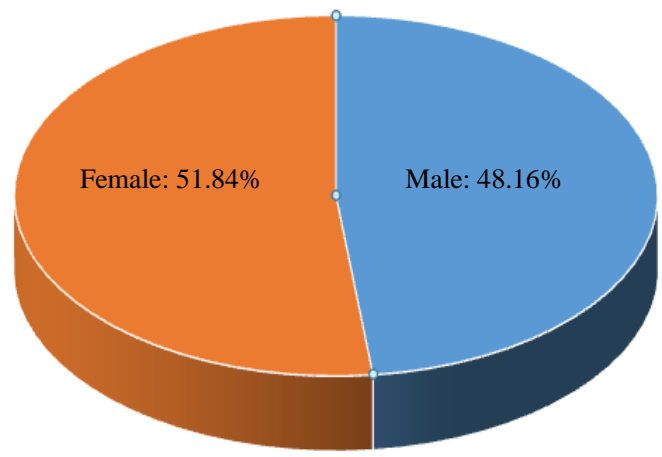

Fig. 3. Gender distribution among HBV-positive cases $(n=245)$.

Of $245 \mathrm{HBsAg}$-positive cases, 55 were $\mathrm{HBeAg}$ positive with a sero-occurrence of $1.12 \%$. Among HBsAg-positive cases, 20 males were positive for $\mathrm{HBeAg}$, and 98 males were negative for $\mathrm{HBeAg}$, and the sero-occurrence of $\mathrm{HBeAg-positive} \mathrm{males} \mathrm{was}$ $36.36 \%$. The highest numbers of HBeAg-positive cases were observed in 21-30-year-old males. Of $55 \mathrm{HBeAg}$ cases, 35 were females, and the rest were non-reactive for $\mathrm{HBeAg}$; all these total female groups were statistically significant $(p<0.039)$ as compared to HBeAg male group by using Z-test, Also, the prevalence of $\mathrm{HBeAg}$-positive females was $63.64 \%$ among HBsAg-positive cases. The age group of 21-30 had the highest seroprevalence $(49.09 \%)$ when compared to other age groups (Table 2). All 245 HBsAg-positive cases were detected for HBV DNA and viral load, except for seven samples that were excluded from PCR due to low volume/spoilage of the samples.

The PCR results showed that $84 \%(n=200)$ of the patients were not detected for HBV DNA, 9.24\% ( $\mathrm{n}=$ 22) were between >threshold $(0.05 \mathrm{IU} / \mathrm{ml})$ and <cutoff $(10 \mathrm{IU} / \mathrm{ml})$, and $6.72 \%(\mathrm{n}=16)$ was $\geq$ cutoff (10 IU/ml). Of these $16 \mathrm{PCR}$-positive patients, the HBV DNA levels of 7 (43.8\%) were below 2000 $\mathrm{IU} / \mathrm{mL}, 4(25 \%)$ were between $>2000 \mathrm{IU} / \mathrm{mL}$ and $20,000 \mathrm{IU} / \mathrm{mL}$, and $5(3.25 \%)$ were $>20000 \mathrm{IU} / \mathrm{mL}$ (Table 3). All 16 PCR positive samples were sequenced for HBV genotyping and pre-core and basal core mutants (Table 4). The prevalence of HBV GEN
$\mathrm{B}$ and GEN A were $68.8 \%(\mathrm{n}=11)$ and $31.25 \%(\mathrm{n}=$ $5)$, respectively. There was no mutation when the precore and basal core regions were sequenced.

\section{DISCUSSION}

Hepatitis B, as it so happens, has no seasonal distribution worldwide. Among developed nations, the occurrence is more common in adults, especially sexually active individuals, than in children, as well as in urban than rural areas ${ }^{[1,2]}$.In countries like Africa and South America, and some other developing countries, this disease is frequently observed among infants and children and is mostly transmitted vertically, from mother to offspring, or via a close personal contact ${ }^{[1,2]}$. However, in endemic areas, most individuals are infected in perinatal stage or in early childhood, and the carrier rates are approximately $>5-6 \%{ }^{[16]}$. The rate of carriers is lower in temperate regions than in tropical area and in females than in males ${ }^{[17]}$. Children born to HBsAg-positive mothers and those who have been fortunate to avoid being infected perinatally continue to be at an excessive risk of infection in the early years of their life. In households, where individuals are chronically infected, non-sexual contact can also transmit HBVI from person-to-person. Transmission happens primarily through the percutaneous path ${ }^{[3]}$. Other than blood transfusion, some therapeutic, prophylactic and diagnostic methods can also transmit the infection. HBV is extremely infectious and very little quantities of a serum (as low as $0.00001 \mathrm{ml}$ ) would suffice for transmitting the disease. Hence, any process that could carry drops of blood/serum from one individual to another can contribute to the transmission of infection ${ }^{[2]}$. HBV is especially very frequent among narcotics addicts, prostitutes, and male homosexuals. Besides, clinical and paramedical personnel, workers at blood banks, handlers of hemodialysis gadgets, laboratory workers, and personnel working in establishments for the mentally retard individuals could also carry the infection. Outbreaks are known to have occurred among hospital workers and patients ${ }^{[18]}$.

In India, the HBV carrier rate is about $3 \%$. Therefore, the severity of HBVI is most certainly not

Table 2. Sex and Age distribution among HBsAg- and HBeAg-positive patients

\begin{tabular}{|c|c|c|c|c|c|c|}
\hline \multirow{2}{*}{ Age group (Y) } & \multicolumn{2}{|c|}{ HBsAg } & \multirow{2}{*}{ Total $(\%)$} & \multicolumn{2}{|c|}{ HBeAg } & \multirow{2}{*}{ Total (\%) } \\
\hline & Male & Female & & Male & Female & \\
\hline $21-30$ & 69 & 74 & $143(58.37)$ & 8 & 19 & 27 (49.09) \\
\hline $31-40$ & 33 & 29 & $62(25.31)$ & 7 & 13 & $20(36.36)$ \\
\hline $41-50$ & 11 & 15 & $26(10.61)$ & 4 & 3 & $07(12.73)$ \\
\hline $51-65$ & 5 & 09 & $14(5.71)$ & 1 & - & $1(1.81)$ \\
\hline Total (\%) & $118(5.32 \%)$ & $127(4.69 \%)$ & $245(4.97 \%)$ & $20(36.36)$ & $35(63.64)$ & $55(100)$ \\
\hline
\end{tabular}


Table 3. Distribution of HBV DNA Viral among HBsAg- and HBeAg-positive patients

\begin{tabular}{|c|c|c|c|c|c|c|}
\hline \multirow{2}{*}{ HBsAg +ve } & \multicolumn{2}{|c|}{ HBeAg } & \multicolumn{4}{|c|}{ Viral load ( IU/ml) } \\
\hline & - ve & + ve & NTC threshold & >Threshold (0.05) & $\geq$ cutoff (10) & Total \\
\hline 245 & - & 55 & 17 & 22 & 16 & 55 \\
\hline & 190 & - & 183 & - & - & 183 \\
\hline 245 & 190 & 55 & 200 & 22 & 16 & 238 \\
\hline
\end{tabular}

NTC, no template control threshold

negligible. There are $>350$ million chronically infected people in the world, and over $>1$ million die of chronic HBVI (CHBVI) each year. Even though many individuals subsequently gain a state of nonreplicative-infection, the prolonged immunologic response to infection results in the formation of liver cirrhosis, even liver failure, or hepatocellular carcinoma (HCC) in up to $40 \%$ of the infected individuals $^{[16]}$. Incidence of $\mathrm{HBV}$ varies from nation to nation and is subjected to a complicated interplay of behavioral and environmental and the host's factors. In general, the incidence is the lowest in countries with high living standards (e.g. the United States, North America, and Europe) and the highest in underdeveloped or developing countries (China, South East Asia, and South America). The situation in India is alarming; almost 3-4\% of the population is infected with $\mathrm{HBV}$ and $\mathrm{CHB}$, amounting to more than $50 \%$ of hepatitis instances. Thus, given the government's apathetic attitude, the HBV epidemiology in India has become critically relevant to the possibility that India may soon emerge as the country with the largest HBVI pool internationally ${ }^{[5]}$. The current prevailing facts confirmed $4.97 \%$ sero-occurrence much like the research carried out by Rajani and Jais ${ }^{[19]}$ in New Delhi, which pegged it at $4 \%$. The occurrence of sero- positivity has been discovered to be greater than that suggested in other investigations conducted by Bart et $a l .{ }^{[20]}(9.5 \%)$ in Switzerland and Jain et al. ${ }^{[21]}(9.67 \%)$ in Lucknow, India. The HBsAg sero-prevalence has also been observed to be lower than that suggested in other researches performed in different areas of India by Das et al. ${ }^{[22]}(1.2 \%)$ in West Bengal, Khatoon and $\operatorname{Jahan}^{[23]}(4 \%)$ in Sitapur, Malhotra et al. ${ }^{[24]}(1.5 \%)$ in Faridkot (Punjab), Pragati et $a .^{[25]}(1.57 \%)$ in Yavatamal (Maharashtra), and Adisesh et al. ${ }^{[26]}$ $(2.8 \%)$ in Chennai. Variable outcomes of serooccurrence for $\mathrm{HBV}$ have been found to be $1.55 \%$, $1.43 \%, 1.09 \%$ in different studies in India ${ }^{[22,27,28]}$.

Considering the study conducted by Chattopadhyay $^{[29]}$ in New Delhi India, only GENs A (16\%) and D (84\%) were found to be associated with chronic liver disease. On delving into a study conducted by Vivekanandan from South India, GENs $\mathrm{D}, \mathrm{A}$, and $\mathrm{C}$ were detected in $57.3 \%, 18 \%$ and $11.5 \%$, respectively ${ }^{[30]}$. In an examination conducted by Swati et $a{ }^{[31]}$ in the western part of India, GENs D and A were most effectively detected; the former was seen to be primary $(91.93 \%)$, and the latter was observed to occur regularly in $8 \%$. Another study in a post graduate institute at Chandigarh collected GENs D, A, B, and C and in one pattern GEN B and then mixed then with

Table 4. HBV DNA viral load showing GENs and mutation

\begin{tabular}{|c|c|c|c|c|c|}
\hline \multirow{3}{*}{ S.N. } & \multirow{3}{*}{$\begin{array}{c}\text { Viral load } \\
\text { (IU/ml) }\end{array}$} & \multicolumn{4}{|c|}{ Objectives } \\
\hline & & \multicolumn{2}{|c|}{ GEN } & \multicolumn{2}{|c|}{ Mutation } \\
\hline & & Target regions & GenBank No. & Target regions & Pre-core/basal core \\
\hline 1 & $1.00413 \times 10^{6}$ & Pre-S gene & B-D00329 & Pre-core/core & NM \\
\hline 2 & $2.75525 \times 10^{3}$ & Pre-S gene & B-D00329 & Pre-core/core & NS \\
\hline 3 & $4.23150 \times 10^{3}$ & Pre-S gene & A-AF 090842 & Pre-core/core & NM \\
\hline 4 & $2.60000 \times 10^{1}$ & Pre-S gene & B-AB073846 & Pre-core/core & NS \\
\hline 5 & $3.78439 \times 10^{5}$ & Pre-S gene & A-AF 090842 & Pre-core/core & NM \\
\hline 6 & $5.37500 \times 10^{1}$ & Pre-S gene & B-D00329 & Pre-core/core & NS \\
\hline 7 & $7.78550 \times 10^{3}$ & Pre-S gene & B-D00329 & Pre-core/core & NM \\
\hline 8 & $5.72500 \times 10^{1}$ & Pre-S gene & B-D00329 & Pre-core/core & NS \\
\hline 9 & $3.25000 \times 10^{2}$ & Pre-S gene & A-AF 090842 & Pre-core/core & NS \\
\hline 10 & $9.06890 \times 10^{5}$ & Pre-S gene & B-D00329 & Pre-core/core & NM \\
\hline 11 & $3.54425 \times 10^{3}$ & Pre-S gene & A-AF 090842 & Pre-core/core & NM \\
\hline 12 & $7.36287 \times 10^{5}$ & Pre-S gene & B-D00329 & Pre-core/core & NM \\
\hline 13 & $8.39305 \times 10^{5}$ & Pre-S gene & A-AF 090842 & Pre-core/core & NM \\
\hline 14 & $4.35000 \times 10^{1}$ & Pre-S gene & B-AB073846 & Pre-core/core & NS \\
\hline 15 & $1.00000 \times 10^{1}$ & Pre-S gene & B-D00329 & Pre-core/core & NS \\
\hline 16 & $1.12500 \times 10^{1}$ & Pre-S gene & B-D00329 & Pre-core/core & NS \\
\hline
\end{tabular}

Eight PCR positive samples were not sequenced for mutation due to low viral load. NM, no mutation; NS, non-sequenceable 
GEN-D ${ }^{[32]}$. The prevalences of GEN B and GEN A from the isolated HBV DNA were found to be $68.8 \%$ and $31.25 \%$, respectively. GEN B was predominant in our isolates, and the variable consequences were discovered in a one-of-a-kind research performed in a part of India ${ }^{[22,27,28]}$.

Numerous studies carried out outside India have proven the exceptional incidence of GEN $\mathrm{C}$ being predominant in Bangladesh and Taiwan ${ }^{[33,34]}$, while GEN D is dominant in Turkey and $\operatorname{Iran}^{[35,36]}$. Predominance of the HBV GEN-E was detected in Niger $^{[37]}$. The new research works have revealed that acute infection with HBV GEN A could increase the risk of chronic infection. In Japan, instances of HBVI after $\mathrm{CHB}$ has been observed to be greater in patients with GEN A $(23 \%)$ than those with GEN B (11\%) or C $(7 \%)$ infections ${ }^{[38] .}$ Of particular interest is the fact that the increase of acute infections with HBV might bring about a redistribution of $\mathrm{HBV}$ GENs among patients with $\mathrm{CHB}$ in any country wherein the hepatitis B vaccination has not been released yet. For instance, in a nationwide survey, Matsuura et al. ${ }^{[39]}$ have found that the prevalence of $\mathrm{HBV}$ GEN A in $\mathrm{CHB}$ sufferers in Japan increased from $1.7 \%$ all through 2000 to $3.5 \%$ in 2006. GEN F turned into the universal GEN among the CHBVI in the city of Buenos Aires, Argentina, and GEN F showed a propensity to promote an unfavorable disease, thereby resulting in a number of chronic instances $^{[40]}$. Positive HBV GENs and sub-GENs C, $\mathrm{B} 2-5$, and F1 appeared to have a better chance of growing $\mathrm{HCC}$, and other GENs like B1, B6, and A2 seemed to be related to a lower risk of complication of HBV. Those individuals who were infected by GEN C were more likely to develope HCC. Waitlist mortality was the highest amongst patients with GEN D, while incidentally, post-transplant mortality became the highest amongst sufferers with GEN $\mathrm{C}^{[41]}$. In China, HBV co-infections with two or three GENs were related to higher viral-load and development to chronic diseases. HBV B2 infection appears to be associated with $\mathrm{HCC}$ reappearance, and $\mathrm{HBV} \mathrm{C} 2$ was discovered more in $\mathrm{HCC}$ patients ${ }^{[42]}$. In another work from China, it has been demonstrated that HBV GENs B and C are associated with remarkable risk of chronic-stage liver sicknesses, which necessitates transplantation. GEN C also seemed to convey a more hazardous severity of reappearance due to lamivudine-resistant mutants ${ }^{[43]}$.

In North India, GEN A is very frequently related with ALT increase, HBeAg-positivity, and absence of anti-HBe, and amongst adults above 25 years, it is more associated with liver cirrhosis than GEN $D^{[44]}$. Sufferers with HCC and GEN C had greater chances of tumor recurrences after resection of $\mathrm{HCC}$ as compared to those with GEN B ${ }^{[45]}$. In a study conducted in Spain that covered both interferon-treated and untreated pateints, those infected with GEN F had been shown to have decreased cumulative opportunity of sustained biochemical remission and HBV DNA loss and a substantially rates of liver failure than those infected with GEN D or A virus ${ }^{[46]}$. An observation from India has stated that GEN D is related to greater extreme liver disease and HCC in more youthful sufferers than GEN $\mathrm{A}^{[47]}$. In Taiwan, GEN $\mathrm{C}$ was associated with more severe liver disease, and GEN B was correlated with the improvement of HCC in young non-cirrhotic sufferers. In comparison, GEN B had a favorably more suitable analysis in Japan and China and was actually related to the improvement of HCC. Similarly, GEN D had a connection with more strong liver disorder than GEN A, which were mostly associated with HCC in younger infected individuals in India ${ }^{[48]}$.

In respect to sex-related prevalence, this research showed $5.32 \%$ sero-occurrence in males and $4.69 \%$ prevalence in females. The high sero-occurrence of HBsAg in males was accountable for the overall high prevalence in all the patients. The basal core promoter dwelling within the overlapping $\mathrm{X}$ open reading frame region controls the transcription of each $\mathrm{PC}$ and core areas $^{[34]}$. PC mutations are frequently associated with $\mathrm{C}$ gene mutations/deletions. Several types of pc/core mutants had been defined in numerous parts of the world and are seen as being related to increased danger of HCC in addition to the progression of liver diseases. In our research, we have not detected any mutation in surface gene and $\mathrm{C}$ gene because this study was prevalence-based research, and this may be the reason why no detection of any mutation transpired in the basal core promoter and $\mathrm{PC}$ region. On having a look at the prevailing trend $\mathrm{HBV}$, the sero-occurrence was associated with the relation of age. The positivity for an active carrier turned additionally higher. A higher occurrence of HBsAg detected in this study is presumptively because of the lack of immunization against this virus. The higher occurrence was also directly correlated with the presence of an uneducated populace and unlicensed practitioners, who for numerous decades have taken the advantage of the lack of consumer evidence inside the clinical services arcade and misguided patients to take redundant injections, in developing nations like India.

The current research shows that the sero-occurrence of HBV was the highest among males. The most predominant HBV sero-prevalence was observed in the age group of 21-30 in both genders, and this may be due to higher sexual activity of this age group. No precore and basal core mutants were detected by sequencer, and GEN B was more prevalent in comparison to GEN A. 


\section{ACKNOWLEDGEMENTS}

The authors are grateful to Dr. Arvind Shukla, Assistant Professor of Community Medicine Netaji Subhash Chandra Bose Subharti Medical College, Swami Vivekanand Subharti University, Meerut, Uttar Pradesh, India for his support in statistical analysis and also thankful to our technician, Mr. Harimohan, for his support in the practical work.

CONFLICT OF INTEREST. None declared.

\section{REFERNCES}

1. World Health Organisation. Epidemiology of hepatitis B virus. Division of Health and Development, WHO 2013.

2. Lavanchy D. Hepatitis B virus epidemiology, disease burden, treatment, and current and emerging prevention and control measures. Journal of viral hepatitis 2004; 11(2): 97-107.

3. Stevens CE, Neurath RA, Beasley RP, Szmuness W. $\mathrm{HBeAg}$ and anti-HBe detection by radioimmunoassay: Correlation with vertical transmission of hepatitis B virus in Taiwan. Journal of medical virology 1979; 3: 237-241.

4. Alter MJ. Epidemiology of hepatitis B in Europe and worldwide. Journal of hepatology 2003; 39: 64-69.

5. Chowdhury A., Epidemiology of hepatitis B virus infection in India. Heatits B annual 2004; 1(1): 17-24.

6. Norder, H, Couroucé, AM, Magnius, LO. Complete genomes, phylogenetic relatedness, and structural proteins of six strains of the hepatitis B virus, four of which represent two new genotypes. Virology 1994; 198(2): 489-503.

7. Stuyver, L, De Gendt, S, Van Geyt, C, Zoulim F, Fried M, Schinazi RF, Rossau R. A new genotype of hepatitis $B$ virus: complete genome and phylogenetic relatedness. Journal of general virology 2000; 81(Pt 1): 67-74.

8. Arauz-Ruiz P, Norder H, Robertson BH, Magnius, LO. Genotype H: a new Amerindian genotype of hepatitis B virus revealed in Central America. Journal of general virology 2002; 83(Pt 8): 2059-2073.

9. Morozov, V, Pisareva, M, Groudinin, M. Homologous recombination between different genotypes of hepatitis B virus. Gene 2000; 260(1-2): 55-65.

10. Bowyer SM, Sim JG. Relationships within and between genotypes of hepatitis B virus at points across the genome: footprints of recombination in certain isolates. Journal of general virology 2000; 81(Pt 2): 379-392.

11. Karin Kidd-Ljunggren, Erling Myhre, and Jonas Bläckberg. Clinical and serological variation between patients infected with different hepatitis B virus genotypes. Journal of clinical microbiology 2004; 42(12): 5837-5841.

12. Sugiyama M, Tanaka $Y$, Kato T, Orito E, Ito K, Acharya SK, Gish RG, Kramvis A, Shimada T, Izumi N, Kaito M, Miyakawa Y, Mizokami M. Influence of hepatitis B virus genotypes on the intra- and extracellular expression of viral DNA and antigens. Hepatology 2006; 44(4): 915-924.
13. Liu CJ, Jeng YM, Chen CL, Cheng HR, Chen Ting-Chi Chen PJ, Liu CJ, Lai MY, Chen DS, Kao JH. Hepatitis $\mathrm{B}$ virus basal core promoter mutation and DNA load correlate with expression of hepatitis B core antigen in patients with chronic hepatitis B. The journal of infectious diseases 2009; 199(5): 742-749.

14. Petrosillo N, Ippolito G, Solforosi L, Varaldo PE, Clementi M, Manzin A. Molecular epidemiology of an outbreak of fulminant hepatitis B. Journal of clinical microbiology 2000; 38(8): 297-281.

15. Hunt CM, McGill JM, Allen MI, Condreay LD. Clinical relevance of hepatitis B viral mutations. Hepatology 2000; 31(5): 1037-1044.

16. Wright TL. Introduction to chronic hepatitis B infection. The American journal of gastroenterology 2006; 101(Suppl 1): S1-S6.

17. Manno M, Cammá C, Schepis F, Bassi F, Gelmini R, Giannini F, Miselli F, Grottola A, Ferretti I, Vecchi C, De Palma M, Villa E. Natural history of chronic HBV carriers in northern Italy: morbidity and mortality after 30 years. Gastroenterology 2004; 127(3): 756763.

18. Joshi SK, Ghimire GR. Serological prevalence of antibodies to human immunodeficiency virus (HIV) and hepatitis B virus (HBV) among healthy Nepalese malesa retrospective study. Kathmandu university medical journal (KUMJ) 2003; 1(4): 251-255

19. Rajani M, Jais M. Magnitude and pattern of hepatitis B infection in clinically suspected infectious hepatitis at a tertiary care hospital in urban India. Journal of global infectious disease 2014; 6(3): 105-108.

20. Bart PA, Jacquier P, Zuber PL, Lavanchy D, Frei PC. Seroprevalence of HBV (anti-HBc, HBsAg and antiHBs) and HDV infections among 9006 women at delivery. Liver 1996; 16(2): 110-116.

21. Jain P, Prakash S, Gupta S, Singh KP, Shrivastava S, Singh DD, Singh J, Jain A. Prevalence of hepatitis A virus, hepatitis $\mathrm{B}$ virus, hepatitis $\mathrm{C}$ virus, hepatitis $\mathrm{D}$ virus and hepatitis $\mathrm{E}$ virus as causes of acute viral hepatitis in North India: A hospital based study. Indian journal of medical microbiology 2013; 31(3): 261-265.

22. Das BK, Gaven BK, Aditya Subhra. Seroprevalence of HBV in West Bengal. The journal of infectious diseases $2011 ; 4: 2$.

23. Khatoon R, Jahan N. Evaluation of seroprevalence of Hepatitis $\mathrm{B}$ virus infection among patients attending a hospital of semi-urban North India using rapid immunoassay test. The Nigerian postgraduate medical journal 2016; 23(4): 209-214.

24. Malhotra R, Soin D, Grover P, Galhotra S, Khutan H, Kaur N. Hepatitis B virus and hepatitis C virus coinfection in hemodialysis patients: A retrospective study from a tertiary care hospital of North India. The journal of natural science 2016; 7(1): 72-74.

25. Bulle A, Suchita PT, Gedam SS, Vivek DG, Dugesh D. Prevalence of hepatitis B surface antigen (HBsAg) positivity among general population in Yavatmal (Maharashtra), India. International journal of current microbiology and applied sciences 5: 513-517.

26. Adisesh M, Natesan T, Elumalai S, Subramanian K. A seroprevalence evaluation study of hepatitis B virus, 
hepatitis $\mathrm{C}$ virus and herpes simplex virus- 2 among a special study group. International journal of medical research and health sciences 2016, 5(5):196-199.

27. Meena M, Jindal T, Hazarika A. Prevalence of hepatitis $\mathrm{B}$ virus and hepatitis $\mathrm{C}$ virus among blood donors at a tertiary care hospital in India: a five-year study. Transfusion 2011; 51(1): 198-202.

28. Giri PA, Deshpande JD, Phalke DB, Karle LB. Seroprevalence of transfusion transmissible infections among voluntary blood donors at a tertiary care teaching hospital rural area of India. Journal of family care and primary care $2012 ; \mathbf{1}(1)$ : 48-51

29. Chattopadhyay S, Das BC, Kar P. Hepatitis B virus genotypes in chronic liver disease patients from New Delhi, India. World journal of gastroenterology 2006; 12(41): 6702-6706.

30. Vivekanandan P, Abraham P, Sridharan G, Chandy G, Daniel D, Raghuraman S, Daniel HD, Subramaniam T. Distribution of hepatitis B virus genotypes in blood donors and chronically infected patients in a tertiary care hospital in Southern India. Clinical infectious diseases 2004; 38(9): e81-e86.

31. Gandhe SS, Chadha MS, Arankalle VA. Hepatitis B virus genotypes and serotypes in Western India: lack of clinical significance. Journal of medical virology 2003; 69(3): 324-330.

32. Sharma SK, Saini N, Chwla Y. Hepatitis B virus: inactive carriers. Virology journal 2005, 2: 82.

33. Rahman MA, Hakin F, Ahmed M, Rafiqul Ahsan C, Nessa J, Yasmin M. Prevalence of genotypes and subtypes of hepatitis B viruses in Bangladeshi population. Springer plus 2016; 5: 278.

34. Sharma S, Sharma B, Singla B, Chawla YK, Chakraborti A, Saini N, Duseja A, Das A, Dhiman RK. Clinical significance of genotypes and precore/basal core promoter mutations in HBV-related chronic liver disease patients in North India. Digestive diseases and sciences 2010; 55(3): 794-802.

35. Leblebicioglu H, Eroglu C, Members of the Hepatitis Study Group. Acute hepatitis B virus infection in Turkey: epidemiology and genotype distribution. Clinical microbiology and infection 2004; 10(6): 537 541.

36. Yoosefi K, Taheri M, Khosravi S, Saneie-Moghadam E, Mohagheghi Fard A. Genotyping of hepatitis B virus by multiplex PCR in Sistan and Baluchestan Province. Zahedan journal of research in medical sciences 2016; 18(2): e598.

37. Brah S, Moussa S, Inoua A, Alhousseini DM, Daou M, Madougou B, Romera MH, Hamadou A, Adehossi E, Parola P, Colson P. Molecular characterization of hepatitis B virus from chronically-infected patients in Niamey, Niger. International journal of infectious diseases 2016; 45: 18-23.

38. Tatematsu K, Tanaka Y, Kurbanov F, Sugauchi F, Mano S, Maeshiro T, Nakayoshi T, Wakuta M, Miyakawa Y, Mizokami M. A genetic variant of hepatitis B virus divergent from known human and ape genotypes isolated from a Japanese patient and provisionally assigned to new genotype J. Journal of virology 2009; 83(20): 10538-10547.

39. Matsuura K, Tanaka Y, Hige S, Yamada G, Murawaki Y, Komatsu M, Kuramitsu T, Kawata S, Tanaka E, Izumi N, Okuse C, Kakumu S, Okanoue T, Hino K, Hiasa Y, Sata M, Maeshiro T, Sugauchi F, Nojiri S, Joh T, Miyakawa Y, Mizokami M. Distribution of hepatitis $B$ virus genotype among patients with chronic infection in Japan shifting toward an increase of genotype A. Journal of clinical microbiology 2009; 47(5): 14761483.

40. Pezzano SC, Torres C, Fainboim HA, Bouzas MB, Schroder T, Giuliano SF, Paz S, Alvarez E, Campos RH, Mbayed VA. Hepatitis B virus in Buenos Aires, Argentina: genotypes, virological characteristics and clinical outcomes. Clinical and microbiology and infection 2010; 17(2): 223-231.

41. Gaglio P, Singh S, Degertekin B, Ishitani M, Hussain M, Perrillo R, Lok AS. National Institutes of Health Hepatitis B Virus Orthotopic Liver Transplantation Study Group. Impact of the hepatitis B virus genotype on pre- and post-liver transplantation outcomes. Liver transplantation 2008; 14(10): 1420-1427.

42. Yin J, Zhang H, Li C, Gao C, He Y, Zhai Y, Zhang P, Xu L, Tan X, Chen J, Cheng S, Schaefer S, Cao G. Role of hepatitis B virus genotype mixture, subgenotypes C2 and B2 on hepatocellular carcinoma: compared with chronic hepatitis B and asymptomatic carrier state in the same area. Carcinogenesis 2008; 29:1685-1691.

43. Lo CM, Cheung CK, Lau GK, Yuen MF, Liu CL, Chan SC, Fan ST, Wong J. Significance of hepatitis B virus genotype in liver transplantation for chronic hepatitis B. American journal of transplantation 2005; 5(8): 18931900.

44. Li Y, Wang X, Chen F, Ma R, Wen X, Hu L. Clinical significance of a set of single nucleotide polymorphisms of hepatitis B virus core gene in Chinese Han patients with chronic hepatitis B. Journal of medical virology 2008; 80(11): 1885-1890.

45. Chen JD, Liu CJ, Lee PH, Chen PJ, Lai MY, Kao JH, Chen DS. Hepatitis B genotypes correlate with tumor recurrence after curative resection of hepatocellular carcinoma. Clinical gastroenterology and hepatology 2004; 2(1): 64-71.

46. Sanchez-Tapias JM, Costa J, Mas A, Brugera M, Rodes J. Influence of hepatitis B virus genotype on the longterm outcome of chronic hepatitis B in Western patients. Gastroenterology 2002; 123(6): 1848-1856.

47. Thakur V, Guptan RC, Kazim SN, Malhotra V,Sarin SK. Profile, spectrum and significance of $\mathrm{HBV}$ genotypes in chronic liver disease patients in the Indian subcontinent. Journal of gastroenterology and hepathology 2002; 17(2): 165-170.

48. Kao JH, Chen PJ, Lai MY, Chen DS. Genotypes and clinical phenotypes of hepatitis B virus in patients with chronic hepatitis B virus infection. Journal of clinical microbiology 2002; 40(4): 1207-1209. 